\title{
Hypersynchronic Mental Automatisms: An Innovative Psychiatric Hypothesis Reaffirming Its Validity for Fifteen Years
}

\author{
Javier Alvarez-Rodriguez \\ Jefe de Servicio de Psiquiatría, Complejo Asistencial Universitario de León, León, Spain \\ Email: jar1950@hotmail.com
}

Received 28 October 2014; revised 13 December 2014; accepted 27 December 2014

Copyright (C) 2015 by author and Scientific Research Publishing Inc.

This work is licensed under the Creative Commons Attribution International License (CC BY).

http://creativecommons.org/licenses/by/4.0/

(c) (i) Open Access

\section{Abstract}

This paper deals with certain psychic automatisms that are usually diagnosed as psychiatric symptoms or as simple partial seizures. These mental automatisms are described in many writings by mystics, philosophers, literates, composers, and many different great artists and creators from human history, but they have never conferred any pathological value on these experiences. We have carried out previous scientific researches in which we found abundant arguments suggesting that these automatisms are due to neuronal nets physiologically adapted to fire in a hypersynchronous way. With these pieces of information we propose an audacious hypothesis: these automatic experiences are manifestations of a cognitive cerebral function that, until now, has been insufficiently delimited. We propose the term hyperia to denominate this cognitive function, which we consider responsible for clairvoyant and/or telepathic cognitions. Finally, we discuss the relevant consequences of this hypothesis, particularly in the fields of epilepsy, psychiatry, and neuropsychopharmacology.

\section{Keywords}

Bipolar Disorder, Glutamate, Hippocampus, Learning, Long-Term Potentiation, Schizophrenia, Reflex Epilepsies

\section{Introduction}

This paper is connected with two previous others: the first was published in Spanish as a doctoral thesis in medicine sixteen years ago [1], and the second was written in English as a scientific paper thirteen years ago [2]. In these earlier investigations we had described an innovative neuropsychiatric approach that postulated a new 
cerebral activity or, at least, an activity so far insufficiently delimited. We proposed to denominate this neuronal activity with the neologism hyperia.

This current article appears as a necessary update on this topic. Its primary purpose is to show the consistence and/or validity of our hypothesis. Indeed, in this edition we have included about fifty pieces of research that appeared in recent years, which conclude with findings and evidences that reinforce our initial approach of yesteryear.

Throughout this paper we will describe the following sections:

1) Gradual nature of the research process leading to the hypothesis of hyperia.

2) Definition and description of the hyperic cognitive function.

3) Discussion of the consequences of the hyperic paradigm. In fact, this daring proposal entails psychiatric changes of such magnitude that it constitutes a new paradigm that allows us to explain and to solve some of the main deficiencies and/or contradictions of the current psychiatric model.

4) Conclusions.

\section{Gradual Nature of the Research Process Leading to the Hypothesis of Hyperia}

The first argument supporting the validity of this hypothesis is the progressive and gradual way in which it was originated. Indeed, after some initial indications we found new evidences to strengthen those early signs. The apparition of this spontaneous and growing flow of scientific information congruent with hyperic hypothesis constitutes the first basis or argument supporting it. This gradual investigative process was described in detail in previous publications [1]-[3] and now we summarize it as follows:

\subsection{Melancholic Depression in the Christian Mysticism}

The research process began with the analysis of the mystical phenomenon called passive purification of the spirit by St John of the Cross. The monk and poet of the Spanish Golden Age described in his book Noche Oscura (Dark Night) a set of automatic psychic manifestations, that is, ones that were passively experienced. These psychic phenomena correspond exactly to the psychopathological description of melancholic depression and mania. These painful depressive phases alternate with others of ecstatic and joyful exaltation, just like the alternation of melancholy and mania in bipolar disorder [4] [5].

\subsection{Presence of Other Psychic Automatisms in Christian Mysticism as Well as in the Main Artistic and Intellectual Creations of Humanity}

We were so much surprised with this similarity between passive purification and bipolar disorder that, from then on, we conducted an analysis of the entire prose work of St John of the Cross and also of the writings of other mystics, both Christians and non-Christian. We found that many mystics, from all periods and cultures, described, as part of the extraordinary mystical phenomenology, not only stages of mania and depression, but also other psychic automatisms [6]. These various psychic experiences always have the same phenomenological features, namely: suddenness; inner time distortion; passive or automatic nature of the experience; great intensity of the experience, because the attention is completely focused on the psychic manifestation that passes passively by the mind; and a strong feeling of strangeness due to the peculiarity of the psychic automatism that is occurring, because the subject always experiences it as a strange new world that suddenly bursts into his/her familiar world. Curiously, these traits are the defining features of the epileptic aura [7].

The analysis of déjà vu will help us to understand the kind of experiences we are referring to. Déjà vu is a sudden irruption in consciousness of certainty that an event that we are currently seeing or living has been experienced in the past in the same exact way. According to Devinsky and Luciano, most people have experienced this phenomenon and it can be interpreted as a partial seizure when there is a congruent electroencephalographic study [8]. Well, this paramnesia has all the phenomenological features mentioned earlier: suddenness, automatic nature, great intensity of the experience, and strong feeling of strangeness.

Besides déjà vu and other paramnesias and hypermnesias, mystics of different religions and countries describe the following psychic automatisms: autoscopies; crises of depersonalization and/or derealization; irresistible suicidal and blasphemous impulsions; sudden fits of inhibition and melancholy, often alternating with periods of joyous exaltation; auditory and visual hallucinations or pure cognitions accompanied of the conviction of having 
acquired an irrefutable knowledge, phenomena that are exactly the same as what Jaspers calls primary perceptions and delusions [9]. All these psychic manifestations have been described in detail in the papers above referenced [1]-[3].

We found this overlap between psychopathology and mysticism so striking that it aroused a primary question: if spiritual people of different periods, countries and religions never gave these psychic experiences any morbid value, why do we have to interpret them necessarily as something pathological?

Indeed, we find all these psychic automatisms happened to philosophers and thinkers of all times, including Plato, St Augustine, Kierkegaard, Schopenhauer, Nietzsche, Jean Paul Sartre, Edith Stein and Emil Cioran; as well as to scientists like Archimedes, Pascal and Newton; to mystics like St Paul, Cassian, St Hildegard of Bingen, Meister Eckhart and his disciples John Tauler and Blessed Henry Suso, Blessed Angela of Foligno, St Ignatius of Loyola, St Teresa of Ávila, St John of the Cross, Jean Joseph Surin and Simone Weil; novelists like Dostoevski, Proust and Hesse; poets like Walt Whitman, Tagore and Juan Ramón Jiménez; and painters like William Blake, Vincent Van Gogh and Salvador Dalí.

This frequent overlap between genius and psychopathology also aroused the curiosity of eminent thinkers throughout history, including Greek philosopher Aristotle 2500 years ago, but until now no one has been able to give a satisfactory explanation of this paradox.

\subsection{Psychic Automatisms in Psychotoxic Consumers}

If we added to the great characters listed in the previous section all famous authors who have described this same psychic phenomenology, but now self-induced by psychotoxic substances, the list of famous people who experienced psychic automatisms would be endless. On this matter, it is necessary to highlight the writings: The Doors of Perception and Hashish and Mental Alienation, two monographs on the effects caused by cannabis and mescaline, by Aldous Huxley [10] and Moreau de Tours [11] respectively. Specifically, the work of the French psychiatrist contains each and every one of the above-listed automatisms but interpreted as the effect of cannabis.

There are, indeed, countless scientific investigations showing that psychotoxic substances, also called recreational drugs, produce these same passive psychic experiences that spontaneously appear in mystics, philosophers, scientists and artists along different periods of history. Many studies have appeared during the last two decades which attribute these psychic automatisms to glutamatergic neuronal hypersynchronies [12]-[14] and diagnose them as simple partial seizures if there is an EEG that supports this diagnosis.

With the information obtained so far we already have some new evidence that strengthens our weak initial hypothesis that there is no reason to consider these psychic manifestations necessarily as pathological: if our brain has neuroreception points suitable to respond with psychic automatisms when the adequate neurotransmitters act, and if, either spontaneously or under the influence of psychotoxic substances, these psychic automatisms have served to create the most outstanding literary and artistic works of mankind, why then should we continue interpreting them as pathological? Wouldn't it be more logical to consider these psychic productions as the result of a cognitive function that, until now, has been insufficiently known and/or delimited?

With this innovative hypothesis already in mind, our next step was to try to discover the true meaning of different neuronal hypersynchronies until now masked under the generic umbrella of epilepsy. For this purpose it was necessary to perform exhaustive reviews of different forms and varieties of epilepsy. As a result of these bibliographic reviews we found new evidence that strengthened our nascent hypothesis.

\subsection{The Enigma of Reflex Epilepsies}

We call reflex epilepsies [15] [16] those in which the seizure is the result or effect of a particular stimulus. Stimuli causing the seizure are varied and range from simple physical and chemical stimuli, e.g. light, sound, heat, etc., to complex stimuli such as a mathematical task, a chess move, or the evocation and/or saying of a strongly affective sound [17]. The most common and well-known type of reflex epilepsy is the photosensitive epilepsy [18] whose prevalence has greatly increased since the advent of television.

For our purpose, we focused our interest on some specific aspects of the vast field of reflex epilepsies was. First, the concept of self-induced reflex epilepsies: the subject has learned to handle the triggering stimulus to voluntarily cause a pleasant seizure. No less than $25 \%$ of patients with photosensitive epilepsy produce selfinduced seizures looking for these pleasant experiences [19]. 
Second, we were interested in the concept of musicogenic epilepsies because there is increasing evidence that in this kind of reflex epilepsy the true triggering stimulus is the emotional burden contained in a piece of music [20]-[22]. This issue raised a third important concept for our hypothesis, that is, the so-called affective reflex epilepsies [23] [24] in which the triggering stimulus is an emotional state. Indeed, there is increasing evidence of the existence of these emotional-related seizures [25] [26]. Furthermore, within these epilepsies of an emotional nature we must also include those that are triggered by the pronunciation of certain sounds that have been repeated many times and therefore are loaded with affection [27].

If we pay attention to what we are saying about self-induced seizures we can confirm that this is exactly what mystics and other celebrities learned to do: they use appropriate stimuli (flashing and coloured lights, incenses, monotonous and rhythmic music, repetition and/or meditation of certain sounds, etc.) to awaken those states of ecstatic bliss in their minds, to which they give a spiritual significance.

On the other hand, who has not experienced those feelings of unexpected joy that often comes with uncontrollable sweet tears when listening to certain pieces of music? Should we conclude from this that we all suffer musicogenic reflex epilepsy or would it be preferable to interpret them as physiological neuronal hypersynchronies?

\subsection{Kindling, Long-Term Potentiation, Learning and Memory}

Speaking of seizures produced by repeated stimuli, either flashing lights or monotonous rhythmic musical notes or sounds repeated a thousand times, we will now briefly describe two classic and well-known neurophysiological models of epilepsy, which are also due to repetitive stimuli and provide new evidence that favours our hypothesis: kindling and long-term potentiation.

Kindling and long-term potentiation are two strikingly similar processes in many ways. Both are induced by local application of brief, high-frequency electrical pulse trains through implanted electrodes, and both result in an enhancement in the response to a constant stimulus [28]. Furthermore, long-term potentiation epileptiform response becomes stable and long-lasting since this process entails a neuronal plasticity with apparition of new anatomical structures in neurons [29]. This neurogenesis has been associated with learning and memory, with a great deal of research over the last twenty-five years demonstrating and reinforcing this paradoxical relationship between epileptiform activity and learning and memory, two functions necessary for the survival of the individual and of the species [30]-[32].

Thus, the most epileptogenic and plastic neuronal circuits are also the areas most directly involved in the process of learning and memory. Why, then, are we still considering pathological and epileptic an activity that allows our brain to shape according to the data of all new experiences that happen around us? Wouldn't it be more logical to speak of different neuronal hypersynchronies, among which we can include learning, sleeping, sexual, hyperic and epileptic hypersynchronies?

\subsection{Physiological Nature of Epileptogenesis}

At this stage, we decided to carry out a study on the current knowledge of the electrochemical brain mechanisms of epileptogenesis. According to Sloviter [33], this concept is used to encompass the primary process that causes principal neurons to generate their first spontaneous, multiple population spike-containing epileptiform discharges, whether or not they produce any clinical manifestation.

This analysis provided us with new information, reinforcing our hypothesis that the onset of the epileptic firing seems to be a physiological process. Indeed, many leading epilepsy specialists have suggested the possibility that the beginning of the epileptic process could be physiological: certain areas of the brain (hippocampus, entorhinal and piriform cortex, cerebral amygdale, etc.) seem to be constitutionally prepared to fire in a hypersynchronous way. On this point, Philip Schwartzkroin [34] points out that epilepsy may reflect a basic underlying propensity of the central nervous system. Likewise, Massimo Avoli [35] states that the patterns of activity generated by neurons in the human epileptogenic cortex appear in most instances to be remarkably normal.

Furthermore, although initial bursts traditionally had been considered pro-epileptic and precursors of ictal seizures, there are indications suggesting that initial bursts and posterior spreading seizures are activities opposed and mutually exclusive that appears in different cerebral areas, as Wilson and Bragdon indicate [36]. In the same vein, Karen Gale conceives initial local electrographic seizures as different of propagated seizures [37]. Besides, during the last two decades there has been increasing evidence indicating that the initial focal activity 
could be due to non-NMDA glutamate receptors, while the activity of propagated seizures could be caused by NMDA neurotransmitters, it being necessary that the initial activation had occurred so that the propagating activity could be initiated [38]-[40].

\section{Definition and Description of the Hyperic Cognitive Function}

We have already enough information to develop and describe in detail our hypothesis. There is much evidence indicating that after a first hypersynchrony, there is sometimes a second type of hypersynchrony that could be reactive to that and whose main purpose would be to suppress the initial hypersynchrony when this has become too intense. We propose the first type be called hyperia and reserve the term epilepsy for the second type. The term hyperia is derived from the Greek adverb $\mu^{\prime} \pi \varepsilon \rho$. The New Oxford Dictionary defines hyper as follows: "A prefix meaning, over, beyond the ordinary or normal" [41]. This term refers to the excessiveness [42] implicit during this cerebral functioning mode: an excessive neuronal synchronization; an excessive alignement of consciousness; hyperesthesia of the experience, etc. We think that this neologism is useful to clearly separate and differentiate hyperic and epileptic activities. Furthermore, the use of a single term and always the same, hyperia, avoids the confusion generated by giving different names to the initial hypersynchronous activity: initial bursts, electrographic seizures, non-convulsive seizures, behavioural seizures, etc.

Hyperia, just like the rest of the cognitive cerebral functions, is educable, that is, its functioning can be strengthened through repeated use. Besides, just like all of them, it reaches its operating peak at the end of puberty or early adulthood, and then declines with age. Its manifestations are therefore more frequent and intense in young people than in older people.

Psychic experiences of hyperia always involve a sudden clairvoyant cognition accompanied by telepathic conviction. The Merriam-Webster online dictionary defines clairvoyance as "an ability to communicate with dead people, to predict future events, or to know about things that you did not actually see happen or hear about" [43]. So, the term clairvoyance includes different paranormal phenomena, and clairvoyance and telepathy almost become synonymous.

Again, we will turn to déjà vu to understand better what we are trying to say. During this paramnesia the subject has the feeling of reliving a previously experienced scene, but feels completely unable to associate it with previous memories or experiences. Thus, the subject experiences it as something alien to his own mind and/or will and, so, coming from other different mind. This interpretation of déjà vu as a telepathic phenomenon is more evident when this paramnesia is accompanied by the extrasensory perception of events occurring at a distance, a fact that occurs with relative frequency [44]. Something similar can be said of the autoscopy, an experience in which the individual has the impression that the mind is leaving the body and, so, he/she is able to see it from the outside. This psychic phenomenon is also usually interpreted as a paranormal experience alien to the mind itself [45]-[47].

The same occurs with the sudden fits of melancholic inhibition [48] or the opposite, of ecstatic exaltation [49]. These episodes, which correspond exactly to the psychopathological description of mania and melancholy, are experienced by the subject as something alien to their mind. The phase of manic exaltation is often accompanied by feelings of omnipotence and communion with the Absolute. Meanwhile, the melancholic phase is usually accompanied by delusional ideas of guilt or sin that are also attributed to an external mind, for example, a divine punishment. This is even more evident in schizophrenia-like psychosis, in which there's often a delusional phenomenon that Jaspers [9] called delusional awareness and described in the following terms: "Patients possess a knowledge of immense and universal happenings, sometimes without any trace of clear perceptual experience of them.” (p. 103) For example, Aldous Huxley [50] describes this delusional awareness, triggered by intake of mescaline, as follows:

The Beatific Vision, Sat Chit Ananda, Being-Awareness-Bliss, for the first time I understood, not on the verbal level, not by inchoate hints or at a distance, but precisely and completely what those prodigious syllables referred to (p. 5).

Hermann Hesse [51] offers a very similar description, although now the triggering stimulus of clairvoyant cognition of the Absolute was a piece of music:

It was at a concert of lovely old music. After two or three notes of the piano the door was opened all of a sudden to the other world. I sped through heaven and saw God at work. I dropped all my defences and was 
afraid of nothing in the world. I accepted all things and to all things I gave up my heart (p. 19).

Sometimes the subject is convinced that he has acquired specific clairvoyant knowledge which can only be reached in that special state of consciousness. Thus, St Ignatius of Loyola [52] recounts in his autobiography the following case of multiple clairvoyant cognitions that seemed triggered by the light and acoustic stimuli that came after watching the riverbed:

One day he went to the Church of St Paul, about a mile away from Manresa. Near the road there is a stream, on the bank of which he sat, and gazed at the deep waters flowing by. While seated there, the eyes of his soul were opened. He did not have any special vision, but his mind was enlightened on many subjects, spiritual and intellectual. So clear was this knowledge that from that day everything appeared to him in a new light. Such was the abundance of this light in his mind that all the divine helps received, and all the knowledge acquired up to his sixty-second year, were not equal to it (p. 57).

Scientific researches on these phenomena are often included in the field of parapsychology under the generic term psi phenomena [53]-[56], and although the results are inconclusive, their genesis seems related to the cerebral areas that we have described as more prone to hyperic hypersynchrony, concretely with hippocampal areas [57]-[59].

\section{Discussion of the Consequences of the Innovative Hyperic Hypothesis}

The hypothesis of hyperia has important implications in different neuroscientific fields. For reasons of clarity, we will divide this section into two parts:

1) Facts which heretofore were confusing or contradictory and that the hyperic hypothesis clarifies in a natural and logical way.

2) Changes implicit in the hyperic hypothesis in respect to the neuropsychiatric current model.

\subsection{Facts Confusing or Contradictory That Are Clarified by the Hyperic Hypothesis}

First, our hypothesis makes possible the explanation and clarification of the paradoxical relationship between epilepsy and psychosis, a problem that, according to Starr [60], is one of the great unresolved medical controversies of the twentieth century. On one hand, it is an undeniable fact that epidemiological epileptic activity and psychotic activity appear very often associated in the same subject. On the other hand, these two activities are incompatible simultaneously, as deduced from the clinical observation that generalized seizures put an end to a state of acute psychosis, for example causing such generalized seizures using electro-convulsive therapy. This paradoxical relationship between epilepsy and psychosis is naturally explained by our hypothesis because, according to it, the epileptic hypersynchrony aims to delete a hyperic hypersynchrony that has become excessive.

The hypothesis of hyperia also helps to explain some questions that arise from the psychopharmacological advances in recent decades:

- Why are all anticonvulsant drugs, which are used in psychiatry under the name of mood disorder stabilizers, effective for the treatment of all psychiatric symptoms that in this research we have tagged as "psychic automatisms"?

- Why is there increasing evidence that the last effect that different psychotropic drugs have on the central nervous system is a decrease in neuronal excitability?

The first time we postulated the anticonvulsant role of antidepressant and antipsychotic drugs, sixteen years ago [2], we were confronting the overall stance of psychiatry, which traditionally defended the proconvulsant role of these substances as could be read in the most used handbooks of psychiatry [61]. Since then, much new and strong evidence has appeared, confirming our innovative approach. This evidence does not only refer to the SSRIs and tricyclic antidepressants [62]-[64], but also to antipsychotics, as it is deduced from the increasingly consistent glutamatergic theory of schizophrenia, and also from the abundant information regarding the different role that NMDA and non-NMDA receptors play with respect to neuronal excitability [65]-[67]. These recent studies constitute new arguments supporting our hypothesis of the existence of different hypersynchronies that, additionally, are mediated by different neuroreceptors.

Finally, hyperia explains logically the enigma posed by Aristotle in Problemata $X X X$ in the following terms:

Why is it that all those who have become eminent in philosophy or politics or poetry or the arts are clearly 
of an atrabilious temperament, and some of them to such an extent as to be affected by diseases caused by

black bile, as is said to have happened to Heracles among the heroes? [68]

We need to remember now that melancholy was a polysemic term in Hippocratic medicine, which was the prevailing medical paradigm at the time of the Stagirite. So, melancholy was used not only to refer to body diseases caused by excess of black humour, but also to refer to epilepsy or madness when they were due to this humor [69]. According to our hypothesis, the true eminent activity is hyperia. But, hyperic activity is usually linked with epileptic activity (the Aristotelian black humor) in the same way that fire is linked to the firefighter's water.

\subsection{Changes Implied by the Hyperic Hypothesis Regarding the Current Neuropsychiatric Model}

First, on the concept of epileptogenesis: it seems inappropriate to continue with the use of this name (closely related to the term epilepsy and, therefore, with strong pathological connotations) to describe different forms of neuronal hypersynchronies, some of which appear to have a physiological nature. These hypersynchronies can be better explained as momentary changes of the metastable balance between large-scale integration in favor, for example, of a hyper-ordered processing, as Fingelkurts and Fingelkurts state [70].

Second, our hypothesis implies consequences and major changes from the current psychiatric model, especially with respect to the current classifications of psychiatric disorders. In effect, hyperia constitutes a unique and equal explanation for psychiatric syndromes currently classified as different, such as mania and melancholia (belonging to bipolar disorder), paranoid schizophrenia (belonging to schizophrenic disorders). The fact that all these clinical conditions share the same etiology, pathogenesis and therapeutic response suggests that the Kraepelinian division of endogenous psychoses in manic depressive psychosis (currently termed bipolar disorder) and dementia praecox (currently termed schizophrenia) does not seem to correspond to reality, and perhaps it is necessary to resume the broader concept of endogenous psychoses. A similar conclusion is suggested by a range of genetic research conducted in recent years about schizophrenia. These investigations, far from discovering specific genetic markers for this disorder, detect a set of genetic biomarkers that are present in different psychiatric disorders, such as autism, schizophrenia and bipolar disorder [71]. Furthermore, there is some evidence that genetic findings on schizophrenia differ depending on whether these studies focus on the negative or on the positive syndrome [72].

On the other hand, the polarity psychotic versus not psychotic loses taxonomic importance since hyperia include so much psychotic as not psychotic manifestations, all them having the same nature. However, the dichotomy positive versus negative symptoms gains a great taxonomic importance given that the main psychiatric syndromes can be classified according this criterion.

Perhaps the most important and significant consequence of our hypothesis refers to the alternative therapeutic approach that from now on will need to be applied to mental manifestations of hyperic psychic automatisms. Until now they were considered pathological and were treated as such. From now on, in principle, they do not need any therapy because they are expressions of a productive function of our brain. However, they have been considered for hundreds of years the expression of a disease, so it won't be possible to assimilate this new conception suddenly. Therefore, it is necessary to conduct psycho-educational efforts in order to this important conceptual change can be gradually assimilated. It will be necessary to teach young people experiencing these hyperic phenomena to become familiar with them. Families, teachers, and psychopedagogists also have to realize this new conception in order to help children and youngsters with intense manifestations of hyperia. The numerous advantages of this new approach can be summarized in one sentence: it is preferable to say to a child or teenager: "You are gifted with hyperia", than to tell him: "You have a mental or epileptic illness".

We stated that, in principle, hyperic manifestations are not pathological. However, in some cases they may constitute a disease. When the hypersynchrony reaches such intensity that it that gives way to behaviors with moral or social consequences, then it must be considered a psychiatric illness [73] [74]. Hyperic hypersynchrony can also be interpreted as an illness when the subject is not able to positively integrate the hyperic experiences, but they affect his/her ability to function adequately [75].

Therefore, in opposition to categorical model of illness proposed by current classifications of mental disorders (ICD-10 and DSM-5), hyperic approach advocates a dimensional model with psychic manifestations going from normal to pathological. This dimensional conception will probably contribute to put an end to two important 
problems of current psychiatric paradigm: alarming increase of prevalence of mental disorders, with a prevalence of mental disorders greater than $40 \%$ in North American or Dutch population [76], and the high prevalence of comorbidity of psychiatric disorders [77], with the consequent problems and difficulties linked to such multiple diagnoses.

\section{Conclusions}

Hyperia is a cognitive brain function revealed in the form of psychic automatisms, which are due to the simultaneous depolarization of a great number of neurons that are physiologically adapted to operate in this way. The result of these automatisms is the acquisition by the subject of clairvoyant and/or telepathic cognitions.

This proposal allows us to clarify many pieces of information belonging to different neuroscientific fields (neurophysiology, neurology, psychiatry, psychopharmacology, etc.). In this sense, this approach can be considered a new paradigm according to the meaning of this term: on one hand, it makes it possible to fit together some pieces of information that the current psychiatric paradigm did not allow us to explain until now. On the other hand, the new explanation forces us to reject some information that was conceived hitherto as true and reliable by the neuroscientific community.

\section{References}

[1] Alvarez-Rodriguez, J. (1998) Mística y Epilepsia. Universidad de Murcia, Murcia. https://www.educacion.gob.es/teseo/mostrarRef.do?ref=196587

[2] Álvarez, J. (2001) Neuronal Hypersynchronization, Creativity and Endogenous Psychoses. Medical Hypotheses, 56, 672-685. http://dx.doi.org/10.1054/mehy.2000.1269

[3] Alvarez-Rodriguez, J. (2014) Psychic Neuronal Hypersynchronies: A New Psychiatric Paradigm? Health, 6, 20892099. http://dx.doi.org/10.4236/health.2014.616242

[4] Alvarez-Rodriguez, J., Alvarez-Silva, S. and Alvarez-Silva, I. (2005) Epilepsy and Psychiatry: Automatic Psychic Paroxysms. Medical Hypotheses, 65, 671-675. http://dx.doi.org/10.1016/j.mehy.2005.03.030

[5] Álvarez J. (1997) Mística y depresión: San Juan de la Cruz. Editorial Trotta, Madrid.

[6] Álvarez, J. (2000) Éxtasis sin fe. Editorial Trotta, Madrid.

[7] Ey, H. (1954) Études Psychiatriques, Vol. III. Desclée de Brouwer, Paris.

[8] Devinsky, O. and Luciano, D. (1991) Psychic Phenomena in Partial Seizures. Seminars in Neurology, 11, 100-109. http://dx.doi.org/10.1055/s-2008-1041211

[9] Jaspers, K. (1997) General Psychopathology. The Johns Hopkins University Press, Baltimore and London.

[10] Huxley, A. (1972) The Doors of Perception. Chatto \& Windus, London.

[11] Moreau de Tours, J. (1845) Du hachisch et de l'aliénation mental. Translated by B.B. Milesi, Slatkine Reprints, Genève.

[12] Kantrowitz, J. and Javvit, D.C. (2012) Glutamatergic Transmission in Schizophrenia: From Basic Research to Clinical Practice. Current Opinion in Psychiatry, 25, 96-102.

[13] Moghaddam, B. and Javvit, D. (2012) From Revolution to Evolution: The Glutamatergic Hypothesis of Schizophrenia and Its Implication for Treatment. Neuropsychopharmacology Reviews, 37, 4-15. http://dx.doi.org/10.1038/npp.2011.181

[14] Paz, R.D., Tardito, S., Atzoin, M. and Tseng, K.Y. (2008) Glutamatergic Dysfunction in Schizophrenia: From Basic Neuroscience to Clinical Psychopharmacology. European Neuropsychopharmacology, 18, 773-786. http://dx.doi.org/10.1016/j.euroneuro.2008.06.005

[15] Striano, S., Coppola, A., del Gaudio, L. and Striano, P. (2012) Reflex Seizures and Reflex Epilepsies: Old Models for Understanding Mechanisms of Epileptogenesis. Epilepsy Research, 100, 1-11. http://dx.doi.org/10.1016/j.eplepsyres.2012.01.013

[16] Xue, L.Y. and Ritaccio, A.L. (2006) Reflex Seizures and Reflex Epilepsy. American Journal of Electroneurodiagnostic Technology, 46, 39-48.

[17] Ferlazzo, E., Zifkin, B.G., Andermann, E. and Andermann, F. (2005) Cortical Triggers in Generalized Reflex Seizures and Epilepsies. Brain, 128, 700-710. http://dx.doi.org/10.1093/brain/awh446

[18] Trenité, D.G. (2006) Photosensitivity, Visually Sensitive Seizures and Epilepsies. Epilepsy Research, 70, 269-279. http://dx.doi.org/10.1016/j.eplepsyres.2006.02.012 
[19] Binnie, C.D. (1988) Self-Induction of Seizures: The Ultimate Non-Compliance. Epilepsy Research, 1, 153-158.

[20] Diekmann, V. and Hoppner, A.C. (2014) Cortical Network Dysfunction in Musicogenic Epilepsy Reflecting the Role of Snowballing Emotional Processes in Seizure Generation: An fMRI-EEG Study. Epileptic Disorders, 16, 31-44.

[21] Pittau, F., Tinuper, P., Bisulli, F., Naldi, I., Cortelli, P., Bisulli, A., Stipa, C., Cevolani, D., Agati, R., Leonardi, M. and Baruzzi, A. (2008) Videopolygraphic and Functional MRI Study of Musicogenic Epilepsy. A Case Report and Literature Review. Epilepsy \& Behavior, 13, 685-692. http://dx.doi.org/10.1016/j.yebeh.2008.05.004

[22] Mórocz, I.A., Karni, A., Haut, S., Lantos, G. and Liu, G. (2003) fMRI of Triggerable Aurae in Musicogenic Epilepsy. Neurology, 60, 705-709. http://dx.doi.org/10.1212/01.WNL.0000047346.96206.A9

[23] Schöndiest, M. (2004) Emotional Seizure Precipitation and Psychogenic Epileptic Seizures. In: Wolf, P., Yushi, I. and Zifkin, B., Eds., Reflex Epilepsies: Progress in Understanding, John Libbey Eurotext, Esher, 93-104.

[24] Trimble, M.R. (1986) Hysteria, Hystero-Epilepsy and Epilepsy. In: Trimble, M.R. and Reynolds, E.H., Eds., What Is Epilepsy? Churchill Livingstone, Edinburgh, 192-205.

[25] Novakova, B., Harris, P.R., Ponnusamy, A. and Reuber, M. (2013) The Role of Stress as a Trigger for Epileptic Seizures: A Narrative Review of Evidence from Human and Animal Studies. Epilepsia, 54, 1866-1876. http://dx.doi.org/10.1111/epi.12377

[26] Gilboa, T. (2012) Emotional Stress-Induced Seizures: Another Reflex Epilepsy? Epilepsia, 53, $29-32$. http://dx.doi.org/10.1111/j.1528-1167.2011.03342.x

[27] Reeves, R.R., Kose, S. and Abubakr, A. (2014) Temporal Lobe Discharges and Glossolalia. Neurocase, 20, $236-240$. http://dx.doi.org/10.1080/13554794.2013.770874

[28] Cain, D.P. (1989) Long-Term Potentiation and Kindling: How Similar Are the Mechanisms? Trends in Neurosciences, 12, 6-10. http://dx.doi.org/10.1016/0166-2236(89)90146-X

[29] Teyler, T.J. and DiScenna, P. (1987) Long-Term Potentiation. Annual Review of Neuroscience, 10, 131-161. http://dx.doi.org/10.1146/annurev.ne.10.030187.001023

[30] Takeuchi, T., Duszkiewicz, A.J. and Morris, R.G. (2014) The Synaptic Plasticity and Memory Hypothesis: Encoding, Storage and Persistence. Philosophical Transactions of the Royal Society B: Biological Sciences, 369, Article ID: 20130288. http://dx.doi.org/10.1098/rstb.2013.0288

[31] El-Gaby, M., Shipton, O.A. and Paulsen, O. (2014) Synaptic Plasticity and Memory: New Insights from Hippocampal Left-Right Asymmetries. Neuroscientist. http://dx.doi.org/10.1177/1073858414550658

[32] Park, P., Volianskis, A., Sanderson, T.M., Bortolotto, Z.A., Jane, D.E., Zhuo, M., Kaang, B.K. and Collingridge, G.L. (2013) NMDA Receptor-Dependent Long-Term Potentiation Comprises a Family of Temporally Overlapping Forms of Synaptic Plasticity that Are Induced by Different Patterns of Stimulation. Philosophical Transactions of the Royal Society B: Biological Sciences, 369, Article ID: 20130131. http://dx.doi.org/10.1098/rstb.2013.0131

[33] Sloviter, R.S., Bumanglag, A.V., Schwarcz, R.M. and Frotscher, M. (2012) Abnormal Dentate Gyrus Network Circuitry in Temporal Lobe Epilepsy. In: Noebels, J., Avoli, M., Rogawski, M., Olsen, R. and Delgado-Escueta, A., Eds., Jasper's Basis Mechanisms of the Epilepsies, Oxford University Press, New York, 454-469. http://dx.doi.org/10.1093/med/9780199746545.003.0034

[34] Schwartzkroin, P.A. (2007) Epilepsy: Models, Mechanisms and Concepts. Cambridge University Press, New York.

[35] Avoli, M. (2007) Electrophysiology and Pharmacology of Human Neocortex and Hippocampus in Vitro. In: Schwartzkroin, P.A., Ed., Epilepsy: Models, Mechanisms and Concepts, Cambridge University Press, New York, 244280.

[36] Wilson, W.A. and Bragdon, A. (1993) Brain Slice Models for the Study of Seizures and Interictal Spikes. In: Schwartzkroin, P.A., Ed., Epilepsy: Models, Mechanisms and Concepts, Cambridge University Press, New York, 371387. http://dx.doi.org/10.1017/CBO9780511663314.015

[37] Gale, K. (1993) Focal Trigger and Pathways of Propagation in Seizure Generation. In: Schwartzkroin, P.A., Ed., Epilepsy: Models, Mechanisms and Concepts, Cambridge University Press, New York, 48-93. http://dx.doi.org/10.1017/CBO9780511663314.004

[38] Durstewitz, D. (2009) Implications of Synaptic Biophysics for Recurrent Network Dynamics and Active Memory. Neural Networks, 22, 1189-1200. http://dx.doi.org/10.1016/j.neunet.2009.07.016

[39] Telfeian, A.E. and Connors, B.W. (1999) Epileptiform Propagation Patterns Mediated by NMDA and Non-NMDA Receptors in Rat Neocortex. Epilepsia, 40, 1499-1506. http://dx.doi.org/10.1111/j.1528-1157.1999.tb02032.x

Kelly, J.B. and Zhang, H. (2002) Contribution of AMPA and NMDA Receptors to Excitatory Responses in the Inferior Colliculus. Hearing Research, 168, 35-42. http://dx.doi.org/10.1016/S0378-5955(02)00372-6

[40] Schneiderman, J.H. and Macdonald, J.F. (1989) Excitatory Amino Acid Blockers Differentially Affect Bursting of in Vitro Hippocampal Neurons in Two Pharmacological Models of Epilepsy. Neuroscience, 31, 596-603. 
[41] The Oxford English Dictionary. Clarendon Press, Oxford, 1989.

[42] http://www.thefreedictionary.com/Excessiveness

[43] Clarvoyance. (2011) Merrian-Webster.com. http://www.merriam-webster.com/dictionary/clairvoyance

[44] Gerrans, P. (2014) Pathologies of Hyperfamiliarity in Dreams, Delusions and déjà vu. Frontiers in Psychology, 5, 97. http://dx.doi.org/10.3389/fpsyg.2014.00097

[45] Furlanetto, T., Bertone, C. and Becchio, C. (2013) The Bilocated Mind: New Perspectives on Self-Localization and Self-Identification. Frontiers in Human Neuroscience, 7, 71. http://dx.doi.org/10.3389/fnhum.2013.00071

[46] Occhionero, M. and Cicogna, P.C. (2011) Autoscopic Phenomena and One’s Own Body Representation in Dreams. Consciousness and Cognition, 20, 1009-1015. http://dx.doi.org/10.1016/j.concog.2011.01.004

[47] Brugger, P., Blanke, O., Regard, M., Bradford, D.T. and Landis, T. (2006) Polyopic Heautoscopy: Case Report and Review of the Literature. Cortex, 42, 666-674. http://dx.doi.org/10.1016/S0010-9452(08)70403-9

[48] Alvarez-Silva, I., Alvarez-Rodriguez, J., Alvarez-Silva, S., Perez-Echeverria, M.J. and Campayo-Martínez, A. (2007) Melancholic Major Depression and Epilepsy. Medical Hypotheses, 69, 1046-1053. http://dx.doi.org/10.1016/j.mehy.2007.01.088

[49] Picard, F. and Kurth, F. (2014) Ictal Alterations of Consciousness during Ecstatic Seizures. Epilepsy \& Behavior, 30, 58-61. http://dx.doi.org/10.1016/j.yebeh.2013.09.036

[50] Huxley, A. (1924) The Doors of Perception. http://www.huxley.net/doors-of-perception/aldoushuxley-thedoorsofperception.pdf

[51] Hesse, H. (1963) Steppenwolf. Holt, Rinehart and Winston. http://img0.liveinternet.ru/images/attach/c/0/3716/3716962_hermann_hesse_steppenwolf.pdf

[52] Loyola I (1900) Autobiography. Benzinger Brothers, New York. http://www.gutenberg.org/files/24534/24534-h/24534-h.htm

[53] Noakes, R. (2014) Haunted Thoughts of the Careful Experimentalist: Psychical Research and the Troubles of Experimental Physics. Studies in History and Philosophy of Science Part C, 48 Pt A, 46-56. http://dx.doi.org/10.1016/j.shpsc.2014.07.003

[54] Zanarini, M.C., Frankenburg, F.R., Wedig, M.M. and Fitzmaurice, G.M. (2013) Cognitive Experiences Reported by Patients with Borderline Personality Disorder and Axis II Comparison Subjects: A 16-Year Prospective Follow-Up Study. American Journal of Psychiatry, 170, 671-679. http://dx.doi.org/10.1176/appi.ajp.2013.13010055

[55] Bobrow, R.S. (2011) Evidence for a Communal Consciousness. EXPLORE: The Journal of Science and Healing, 7, 246-248. http://dx.doi.org/10.1016/j.explore.2011.04.001

[56] Utts, J. (1991) Replication and Meta-Analysis in Parapsychology. Statistical Science, 6, 363-378. http://dx.doi.org/10.1214/ss/1177011577

[57] Persinger, M.A. and Saroka, K.S. (2012) Protracted Parahippocampal Activity Associated with Sean Harribance. International Journal of Yoga, 5, 140-145. http://dx.doi.org/10.4103/0973-6131.98238

[58] Venkatasubramanian, G., Jayakumar, P., Nagendra, H., Nagaraja, D., Deeptha, R. and Gangadhar, B. (2008) Investing Paranormal Phenomena: Functional Brain Imaging of Telepathy. International Journal of Yoga, 1, 66-71. http://dx.doi.org/10.4103/0973-6131.43543

[59] Rahey, S. (2004) Prescience as an Aura of Temporal Lobe Epilepsy. Epilepsia, 45, 982-984.

[60] Starr, M.S. (1996) The Role of Dopamine in Epilepsy. Synapse, 22, 159-194. http://dx.doi.org/10.1002/(SICI)1098-2396(199602)22:2<159::AID-SYN8>3.0.CO;2-C

[61] Mendez, M. (2000) Comprehensive Textbook of Psychiatry. In: Sadock, B. and Sadock, V., Eds., Neuropsychiatric Aspects of Epilepsy, Lippincott Williams \& Wilkins, Philadelphia, 261-273.

[62] Mostert, J.P., Koch, M.W., Heerings, M., Heersema, D.J. and De Keyser, J. (2008) Therapeutic Potential of Fluoxetine in Neurological Disorders. CNS Neuroscience \& Therapeutics, 14, 153-164. http://dx.doi.org/10.1111/j.1527-3458.2008.00040.x

[63] Jobe, P.C. and Browning, R.A. (2005) The Serotonergic and Noradrenergic Effects of Antidepressant Drugs Are Anticonvulsant, Not Proconvulsant. Epilepsy \& Behavior, 7, 602-619. http://dx.doi.org/10.1016/j.yebeh.2005.07.014

[64] Albano, C., Cupello, A., Mainardi, P., Scarrone, S. and Favale, E. (2006) Successful Treatment of Epilepsy with Serotonin Reuptake Inhibitors: Proposed Mechanism. Neurochemical Research, 31, 509-514. http://dx.doi.org/10.1007/s11064-006-9045-7

[65] Farazifard, R. and Wu, S.H. (2010) Metabotropic Glutamate Receptors Modulate Glutamatergic and GABAergic Synaptic Transmission in the Central Nucleus of the Inferior Colliculus. Brain Research, 1325, 28-40. http://dx.doi.org/10.1016/j.brainres.2010.02.021 
[66] Sanchez, J.T., Gans, D. and Wenstrup, J.J. (2007) Contribution of NMDA and AMPA Receptors to Temporal Patterning of Auditory Responses in the Inferior Colliculus. Journal of Neuroscience, 27, 1954-1963. http://dx.doi.org/10.1523/JNEUROSCI.2894-06.2007

[67] Wu, S.H., Ma, C.L. and Kelly, J.B. (2004) Contribution of AMPA, NMDA, and GABA(A) Receptors to Temporal Pattern of Postsynaptic Responses in the Inferior Colliculus of the Rat. Journal of Neuroscience, 24, 4625-4634. http://dx.doi.org/10.1523/JNEUROSCI.0318-04.2004

[68] Aristotle (2011) The Works of Aristotle. Oxford: Clarendon Press. http://archive.org/stream/worksofaristotle07arisuoft/worksofaristotle07arisuoft djvu.txt

[69] Jouanna, J. (2012) Greek Medicine from Hippocrates to Galen: Selected Papers. Koninklijke Brill NV, Leiden. http://dx.doi.org/10.1163/9789004232549

[70] Fingelkurts, A.A., Fingelkurts, A.A. and Kähkönen, S. (2005) New Perspectives in Pharmaco-Electroencephalography. Progress in Neuro-Psychopharmacology and Biological Psychiatry, 29, 193-199. http://dx.doi.org/10.1016/j.pnpbp.2004.11.002

[71] Arnedo, J., Svrakic, D.M., Del Val, C., Romero-Zaliz, R., Hernández-Cuervo, H., Molecular Genetics of Schizophrenia Consortium, Fanous, A.H., Pato, M.T., Pato, C.N., de Erausquin, G.A., Cloninger, C.R. and Zwir, I. (2014) Uncovering the Hidden Risk Architecture of the Schizophrenias: Confirmation in the Three Independent Genome- Wide Association Studies. American Journal of Psychiatry, Ahead of Print. http://dx.doi.org/10.1176/appi.ajp.2014.14040435

[72] Alvarez-Rodriguez, J., Alvarez-Silva, S. and Alvarez-Silva, I. (2014) Is the Current Diagnosis of Schizophrenia Useful or Harmful? Open Journal of Medical Psychology, 3, 157-160. http://dx.doi.org/10.4236/ojmp.2014.32018

[73] Fuldford, K.W. (2011) Neuroscience and Values: A Case Study Illustrating Developments in Policy, Training and Research in the UK and Internationally. Mens Sana Monographs, 9, 79-92. http://dx.doi.org/10.4103/0973-1229.77428

[74] Kinghorn, W.A. (2011) Whose Disorder? A Constructive Macintyrean Critique of Psychiatric Nosology. Journal of Medicine and Philosophy, 36, 187-205. http://dx.doi.org/10.1093/jmp/jhr006

[75] Jahoda, M. (1958) Current Concepts of Positive Mental Health. Basic Books, New York. http://dx.doi.org/10.1037/11258-000

[76] Kesller, R.C., Ciu, W.T., Deler, O. and Walters, E.E. (2005) Prevalence, Severity, and Comorbidity of Twelve-Month DSM-IV Disorders in the National Comorbidity Survey Replication (NCS-R). Archives of General Psychiatry, 62, 617-627. http://dx.doi.org/10.1001/archpsyc.62.6.617

[77] Not Authors Cited (2000) Cross-National Comparisons of the Prevalences and Correlates of Mental Disorders. WHO International Consortium in Psychiatric Epidemiology. Bulletin of the World Health Organization, 78, 413-426. 
Scientific Research Publishing (SCIRP) is one of the largest Open Access journal publishers. It is currently publishing more than 200 open access, online, peer-reviewed journals covering a wide range of academic disciplines. SCIRP serves the worldwide academic communities and contributes to the progress and application of science with its publication.

Other selected journals from SCIRP are listed as below. Submit your manuscript to us via either submit@scirp.org or Online Submission Portal.
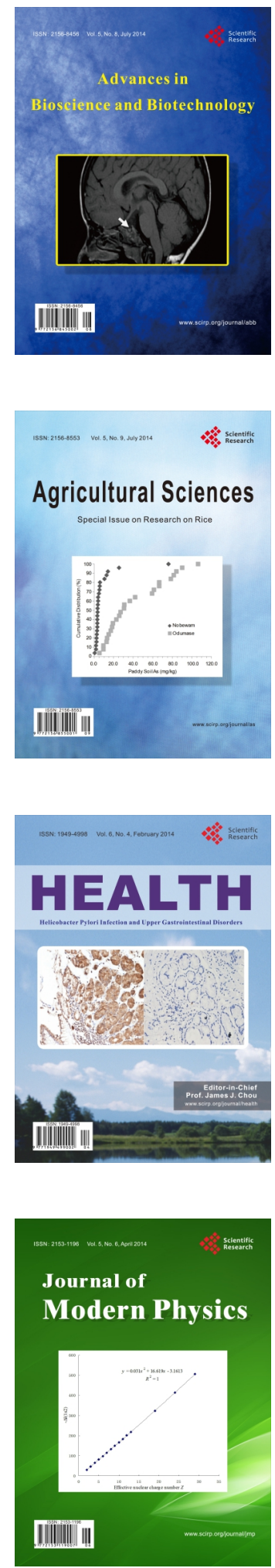
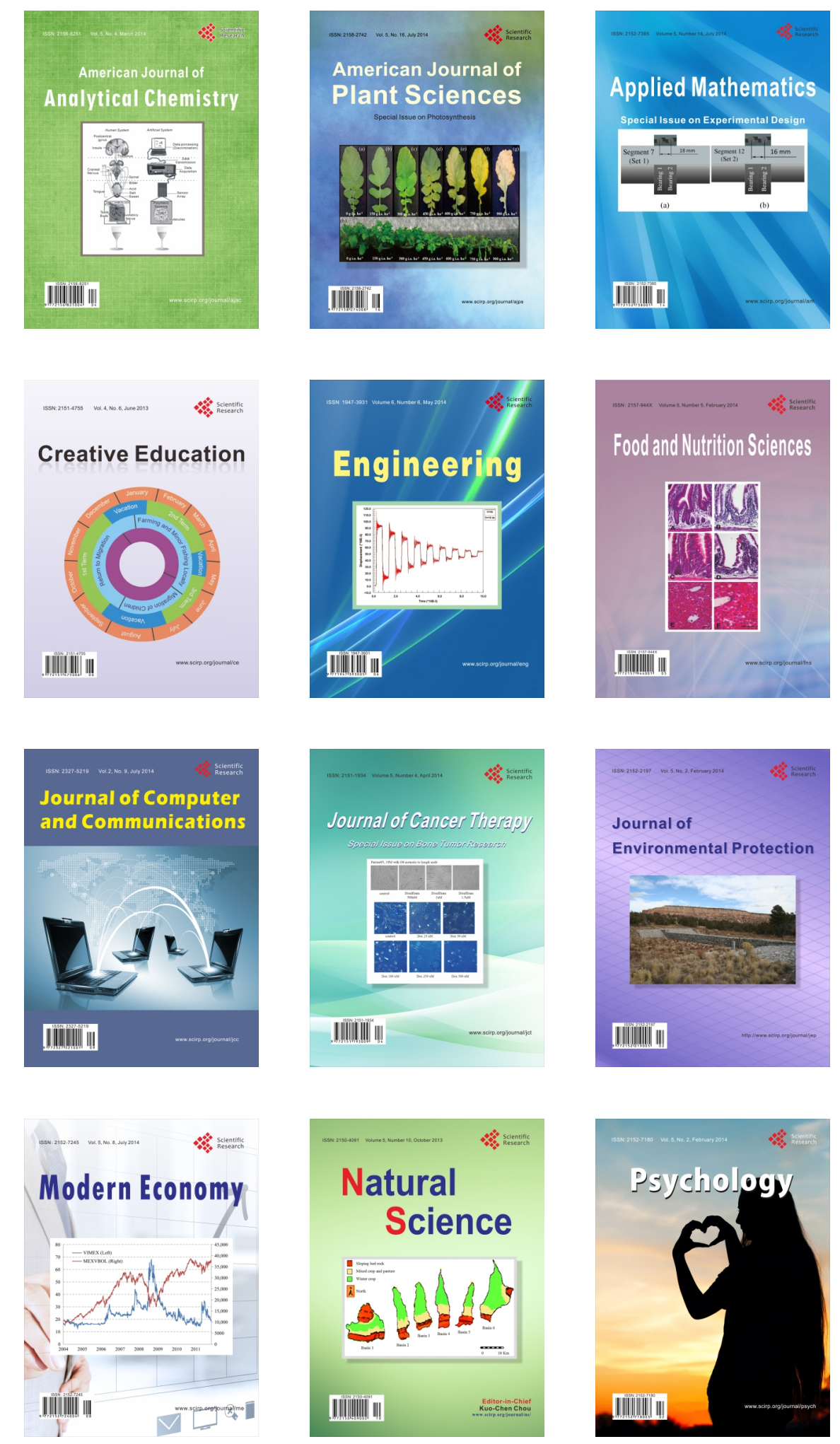